\title{
Installation of submarine cables and pipes in shallow waters and connecting them to the shore by the method of horizontal directional drilling
}

\author{
Valeriu-Florian Vasilescu, ${ }^{1, *}$ and Dumitru Dinu $^{2}$ \\ ${ }^{1}$ Constanta Maritime University, Doctoral School of Mechanical Engineering and Mechatronic, 104 \\ Mircea cel Batran Street, ZC 900663, Constanta, Romania \\ ${ }^{2}$ Constanta Maritime University, Doctoral School of Mechanical Engineering and Mechatronic, 104 \\ Mircea cel Batran Street, ZC 900663, Constanta, Romania
}

\begin{abstract}
This article presents the horizontal directional drilling (HDD) as one of the most suitable technique used to reduce the impact on the environment during the submarine pipe and cable installation process, especially in the coastal area and shallow waters. HDD is a technique used to drill a subsea tunnel or under other designated area with the goal to pull a pipe or other facility through the drilled underground tunnel. With the development of the offshore natural gas and wind industry, the demand for the construction of transfer pipeline and cables has also increased. The installation of submarine pipelines and cables can have negative effects on the marine environment. This is one of the main reasons that construction and operation of offshore wind energy systems has been and continues to be regarded with scepticism by environmental activists, despite the undeniable benefits of this renewable energy source. The main objectives of this article are to emphasize the importance of using this technique but also to highlight the benefits, in particular by significantly reducing the impact on the marine environment.
\end{abstract}

\section{Short description of horizontal directional drilling (HDD)}

HDD is a technique used to drill a subsea tunnel or under other designated area with the goal to pull a pipe or other facility through the drilled underground tunnel. Depending on the desired tunnel's diameter and length, the HDD method is divided into three categories: mini HDD, midi HDD and maxi HDD, their features and applications are shown in Table 1.

Table 1 Classification of HDD method [1]

\begin{tabular}{|c|c|c|c|c|}
\hline Type & $\begin{array}{c}\text { Diameter } \\
\text { range (m) }\end{array}$ & $\begin{array}{c}\text { Crossing } \\
\text { length }(\mathbf{m})\end{array}$ & $\begin{array}{c}\text { Pulling force } \\
(\mathbf{x ~ 1 0} \mathbf{~ N})\end{array}$ & $\begin{array}{c}\text { Machine } \\
\text { weight }(\mathbf{k g})\end{array}$ \\
\hline Mini & $0.05-0.3$ & $\leq 177$ & $>445$ & $\leq 9000$ \\
\hline
\end{tabular}

\footnotetext{
${ }^{*}$ Corresponding author: vasilescuvaleriu75@gmail.com
} 


\begin{tabular}{|c|c|c|c|c|}
\hline Midi & $0.3-0.6$ & $\leq 274$ & $90-445$ & $\leq 18000$ \\
\hline Maxi & $0.6-1.5$ & $\leq 3058$ & $<90$ & $\leq 30000$ \\
\hline
\end{tabular}

In HDD there are considered three main installation stages (Fig. 1):

- $\quad$ Pilot drilling

- $\quad$ Reaming the initial pilot borehole

- Pulling back the pipeline in the reamed borehole or the cable through the installed pipe

When drilling a wellbore, a pilot hole is drilled mainly for safety reasons. The wellbore is drilled using a drilling fluid, which has the role of cooling and lubricating the drill bit but also to transport the material displaced by the bit to the surface through the annular space outside the drill string. The drilling fluid is pumped into the wellbore through the hydraulic head at a high-pressure rate. Next step is to enlarge the pilot hole using a reamer. The reamer is a down hole tool able to enlarge a borehole gradually, depending on drilling program requirements. At the end of drilling the wellbore, the drill string is pulled out, but during the whole period of drilling and extracting the drill string, the drilling fluid is present in the well.

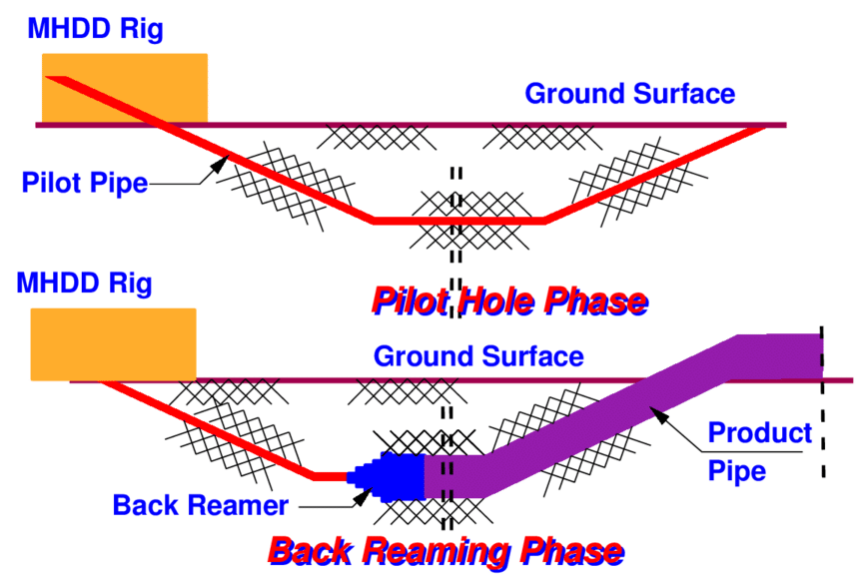

Fig. 1 HDD layout [2]

One of the biggest challenges in an installation process of submarine pipes or cables, by using the HDD technique, is the one due to the lack of qualified personnel. At the same time, insufficient geotechnical information and the lack of drilling profiles can lead to the impossibility of performing a horizontal directional drilling. Due to the technological innovations that HDD has known in recent past years, this technique can meet the latest engineering requirements. By modernizing the pipe handling equipment, it was possible to increase the drilling speed as well as the degree of operational safety.

Before deciding to install submarine cables or pipes using HDD, at least the following aspects must be taken into account:

- the preliminary geological survey report should provide at least the following information: plane map, geological profile, sampling depth, water content, saturation, granularity, standard penetration number, liquid index, plastic index, liquid limit, plastic limit and so on

- the geological conditions that HDD is suitable for crossing include clay, mild clay, well-forming sand, and soft rock

- the design radius of the drilling has to be larger than the minimum allowable bending radius of the cable, pipe and of the drill string 
- the curvature radius of the pipeline should be as large as possible, so as to avoid the increase of pullback resistance

- the entrance angle and exit angle should be determined according to the topography, geological conditions and the diameter of the pipeline. Generally, the entrance angle should be controlled at 8 to 18 degrees and the exit angle should be controlled at 4 to 12 degrees. At present, the maximum entrance angle can reach 28 degrees and the exit angle can reach 15 degrees.

The main components of HDD are presented in Fig.2

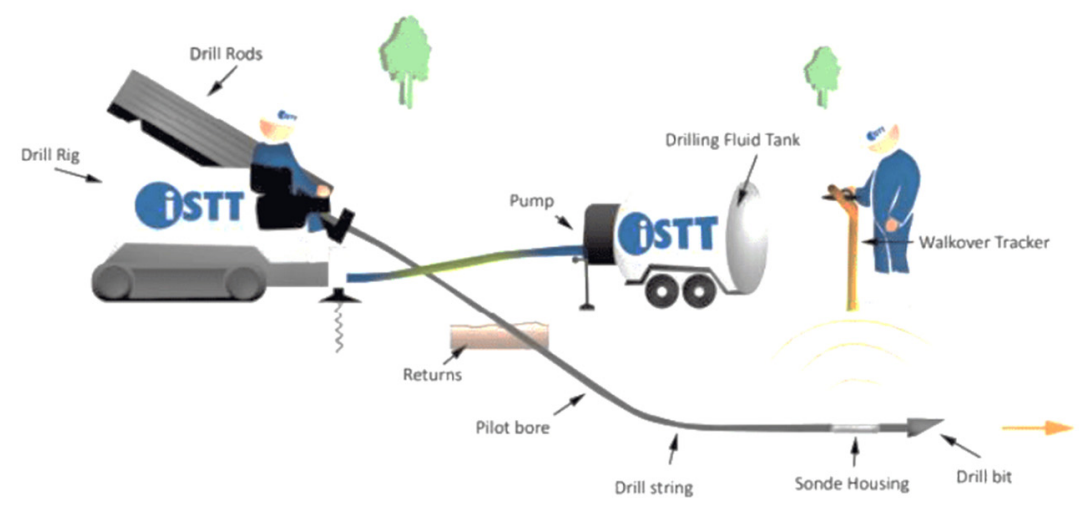

Fig. 2 Components of HDD [3]

\section{Design of a drilling radii}

The design of a drilling radii plays an important role and the Drilling Contractors Association (DCA) guideline recommends using a design radius, which considers also the drill ability by a constant for the individual geological condition. The drilling radii can be calculated with the following formula [4]:

$$
R_{\text {design }}=C \sqrt{D t}
$$

Were:

$\mathrm{R}_{\text {design }}=$ design radius

$\mathrm{C}=$ soil characteristic constant (Table 2)

$\mathrm{D}=$ outer pipe diameter

$\mathrm{t}=$ pipe wall thickness 
Table 2 Soil parameters

\begin{tabular}{|c|c|c|c|c|}
\hline \multirow{2}{*}{ CONDITION } & $\begin{array}{c}\text { Cone } \\
\text { Penetration } \\
\text { Test (CPT) }\end{array}$ & $\begin{array}{c}\text { Standard } \\
\text { Penetration } \\
\text { Test }(\mathrm{SPT})\end{array}$ & $\begin{array}{c}\text { Elastic } \\
\text { modulus } \\
\text { Es }\end{array}$ & $\begin{array}{c}\text { Soil characteristic } \\
\text { constant } \\
\mathrm{C}\end{array}$ \\
\cline { 2 - 5 } & $\mathrm{qc}[\mathrm{MPa}]$ & $\begin{array}{c}\mathrm{N}_{30} \\
\text { [blows/30 cm] }\end{array}$ & $\begin{array}{c}{[\mathrm{MPa}]} \\
{[-]}\end{array}$ \\
\hline $\begin{array}{c}\text { Sand (very } \\
\text { dense) }\end{array}$ & $>20$ & $>50$ & $100-200$ & 8500 \\
\hline $\begin{array}{c}\text { Sand (medium } \\
\text { density) }\end{array}$ & $10-20$ & $25-50$ & $50-100$ & 9400 \\
\hline $\begin{array}{c}\text { Sand (low } \\
\text { density) }\end{array}$ & $5-10$ & $10-25$ & $20-50$ & 10200 \\
\hline Clay (dense) & $>2$ & $>8$ & $10-25$ & 10500 \\
\hline $\begin{array}{c}\text { Clay (medium } \\
\text { density) }\end{array}$ & $1-2$ & $2-8$ & $5-10$ & 11500 \\
\hline $\begin{array}{c}\text { Soft clay } \\
\text { (silty) }\end{array}$ & $<1$ & $<2$ & $0-5$ & 12500 \\
\hline
\end{tabular}

The soil conditions are of a paramount importance for the planning and design of a horizontal directional drilling.

In order to better understand this very important aspect take a look over the below simulation of a geotechnical onshore and offshore investigation campaign (Table 3).

Lithologically they all show alternating fine to medium sands underlaid by sandy and silty clays, comparable to the beach borehole.

Following these investigations, both the drilling route and the reaming procedure can be decided.

According with the values from the bellow simulation we can conclude that the procedure of push ream is not applicable due to significant number of SPT values that are between 0 and 8 and only a back reaming procedure will be able to be realized.

Table 3 Soil condition

Distance

from

$\begin{array}{lllllllll}\text { entry: } & 100 \mathrm{~m} & 400 \mathrm{~m} & 500 \mathrm{~m} & 600 \mathrm{~m} & 700 \mathrm{~m} & 800 \mathrm{~m} & 900 \mathrm{~m} & 1000 \mathrm{~m}\end{array}$

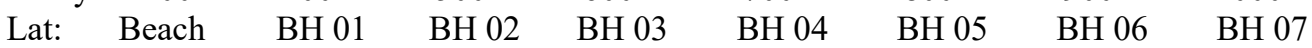

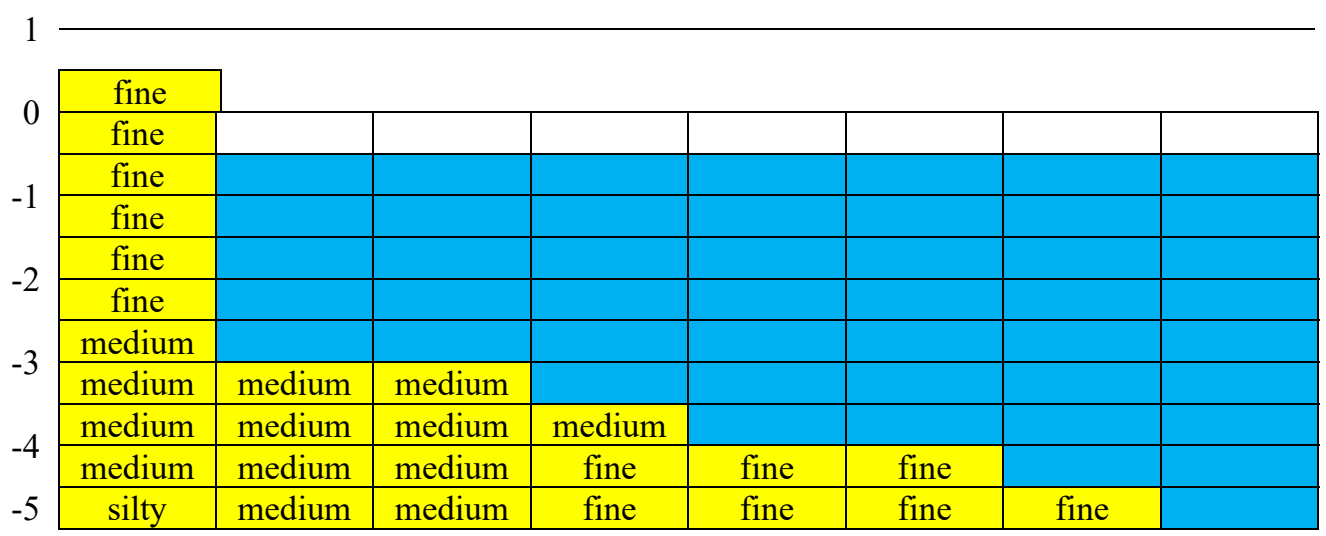




\begin{tabular}{|c|c|c|c|c|c|c|c|c|}
\hline \multirow{3}{*}{-6} & silty & fine & fine & fine & fine & fine & fine & fine \\
\hline & silty & fine & fine & fine & fine & fine & fine & fine \\
\hline & silty & fine & fine & fine & fine & fine & fine & fine \\
\hline \multirow{2}{*}{-7} & silty & fine & fine & fine & fine & fine & fine & fine \\
\hline & silty & fine & fine & silty & silty & silty & silty & silty \\
\hline \multirow{2}{*}{-8} & silty & fine & fine & silty & silty & silty & silty & silty \\
\hline & silty & fine & fine & silty & silty & silty & silty & silty \\
\hline \multirow{2}{*}{-9} & silty & silty & silty & silty & silty & silty & silty & silty \\
\hline & silty & silty & silty & silty & silty & silty & silty & silty \\
\hline \multirow{2}{*}{-10} & silty & silty & silty & silty & silty & silty & silty & silty \\
\hline & silty & silty & silty & silty & silty & silty & silty & silty \\
\hline \multirow{2}{*}{-11} & fine & silty & silty & silty & silty & silty & silty & silty \\
\hline & fine & silty & silty & silty & silty & silty & silty & silty \\
\hline \multirow{2}{*}{-12} & fine & silty & silty & silty & silty & silty & silty & silty \\
\hline & fine & silty & silty & silty & silty & silty & silty & silty \\
\hline \multirow{2}{*}{-13} & fine & silty & silty & silty & silty & silty & silty & silty \\
\hline & fine & silty & silty & silty & silty & silty & silty & silty \\
\hline \multirow{2}{*}{-14} & fine & silty & silty & silty & silty & silty & silty & silty \\
\hline & silty & silty & silty & silty & silty & silty & silty & silty \\
\hline \multirow{2}{*}{-15} & silty & silty & silty & silty & silty & silty & silty & silty \\
\hline & silty & silty & silty & silty & silty & silty & silty & silty \\
\hline \multirow{2}{*}{-17} & silty & silty & silty & silty & silty & silty & silty & silty \\
\hline & silty & silty & silty & silty & silty & silty & silty & silty \\
\hline \multirow{2}{*}{-18} & silty & silty & silty & silty & silty & silty & silty & silty \\
\hline & silty & silty & silty & silty & silty & silty & silty & silty \\
\hline \multirow{2}{*}{-19} & silty & silty & silty & silty & silty & silty & silty & silty \\
\hline & silty & silty & silty & silty & silty & silty & silty & silty \\
\hline \multirow{2}{*}{-20} & clay & silty & silty & silty & silty & silty & silty & silty \\
\hline & clay & silty & silty & silty & silty & silty & silty & silty \\
\hline \multirow{2}{*}{-21} & clay & silty & silty & silty & silty & silty & silty & silty \\
\hline & clay & silty & silty & silty & silty & silty & silty & silty \\
\hline \multirow{2}{*}{-22} & clay & silty & silty & silty & silty & silty & silty & silty \\
\hline & clay & silty & silty & silty & silty & silty & silty & silty \\
\hline \multirow{2}{*}{-23} & clay & silty & silty & silty & silty & silty & silty & silty \\
\hline & clay & silty & silty & silty & silty & silty & silty & silty \\
\hline \multirow{2}{*}{-24} & clay & silty & silty & silty & silty & silty & silty & silty \\
\hline & clay & gravel & gravel & gravel & gravel & gravel & gravel & gravel \\
\hline \multirow{2}{*}{-25} & clay & gravel & gravel & gravel & gravel & gravel & gravel & gravel \\
\hline & clay & gravel & gravel & gravel & gravel & gravel & gravel & gravel \\
\hline
\end{tabular}

\section{Finite Element Analysis (FEA)}

In this section is analysed, by using the ANSYS Workbench software, the pipe stress under a scenario which respects reality as much as possible. Workbench is an integrated environment software released by ANSYS which keep all the functions of ANSYS classic platform in FEA and integrates powerful geometric modelling functions of computer-aided design (CAD). 
In this scenario the size of the pipe is $400 \mathrm{~mm} \times 14 \mathrm{~mm}$ (diameter $\times$ thickness), and the diameter of the borehole is $650 \mathrm{~mm}$. According to Saint Venant's principle, the soil far away from the object has little influence on the analysis, so the width and height of the soil are set at about 11 times the diameter of the borehole, which is $7.2 \mathrm{~m}$. According to Fig. 3 we can observed be that the object of analysis is symmetrical on the X-axis.

In order to save computing time, only half of the models for soil and pipeline are established on the cross section. In addition, the length of the pipe is taken as $5 \mathrm{~m}$ in this analyse. Therefore, the size of the whole model is $3.6 \mathrm{~m} \times 5 \mathrm{~m} \times 7.2 \mathrm{~m}$ (width $\times$ length $\times$ height). The geometric model built with Design Modeler software is shown in Fig.4.

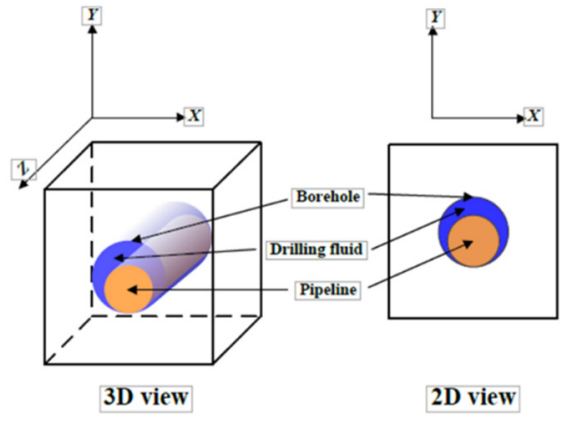

Fig. 3 Physical model of the proposed scenario

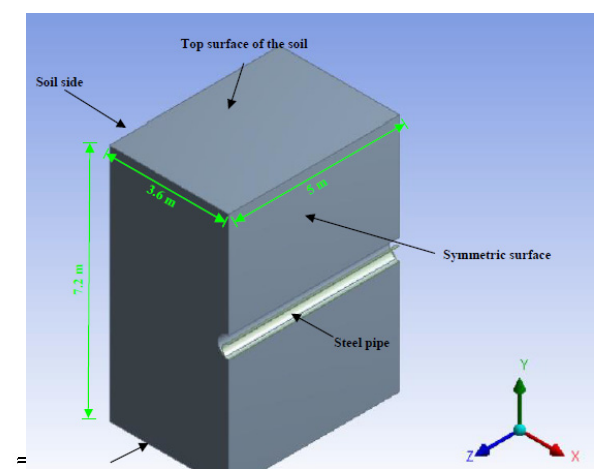

Fig. 4 Pipeline-soil geometric model

For this analyse only mechanical properties of pipe and soil need to be set, as shown in Table 4.

Drucker-Prager model is used for soil, considered closer to the actual scenario.

There is only one contact involved in the model: contact between the inner wall of the borehole and the outer wall of the pipe.

Table 4 : Parameters of the steel pipe and soil

\begin{tabular}{|c|c|c|c|}
\hline $\begin{array}{l}\text { Steel pipe } \\
\text { parameter }\end{array}$ & Value & Soil parameter & Value \\
\hline $\begin{array}{l}\text { Outer diameter } \\
\text { (OD) }\end{array}$ & $400 \mathrm{~mm}$ & Poisson's ratio & 0.2 \\
\hline Wall thickness & $14 \mathrm{~mm}$ & Elastic modulus & $42 \mathrm{MPa}$ \\
\hline Material & API 5Lx52 & $\begin{array}{l}\text { Dilatancy angle } \\
\text { of soil }\end{array}$ & $4.83^{\circ}$ \\
\hline Elastic modulus & $\begin{array}{l}210 \mathrm{GPa}\left(3.046 \times 10^{7}\right. \\
\mathrm{psi})\end{array}$ & $\begin{array}{ll}\begin{array}{l}\text { Internal friction } \\
\text { angle }\end{array} & \\
\end{array}$ & $9.65^{\circ}$ \\
\hline Bulk modulus & $\begin{array}{l}175 \mathrm{GPa}\left(2.538 \times 10^{7}\right. \\
\text { psi) }\end{array}$ & Density & $\begin{array}{l}2500 \quad \mathrm{~kg} / \mathrm{m}^{3} \\
\left(156.07 \mathrm{lb} / \mathrm{ft}^{3}\right)\end{array}$ \\
\hline Shear modulus & $\begin{array}{ll}80.769 & \mathrm{GPa} \\
(11714553 \mathrm{psi}) & \end{array}$ & Cohesion of soil & $12.94 \mathrm{kPa}$ \\
\hline Poisson's ratio & 0.3 & $\begin{array}{l}\text { Borehole } \\
\text { diameter }\end{array}$ & $650 \mathrm{~mm}$ \\
\hline Density & $\begin{array}{l}7850 \quad \mathrm{~kg} / \mathrm{m}^{3} \quad(490 \\
\left.\mathrm{lb} / \mathrm{ft}^{3}\right)\end{array}$ & & \\
\hline
\end{tabular}


Since the bottom of the pipe is in contact with the bottom of the borehole, that is, the normal direction is not separated, the tangential direction may have a small sliding, so that the contact of "frictional" is used, as shown in Fig.5. According to actual engineering data, the coefficient of friction between the pipeline and the soil is 0.24 .
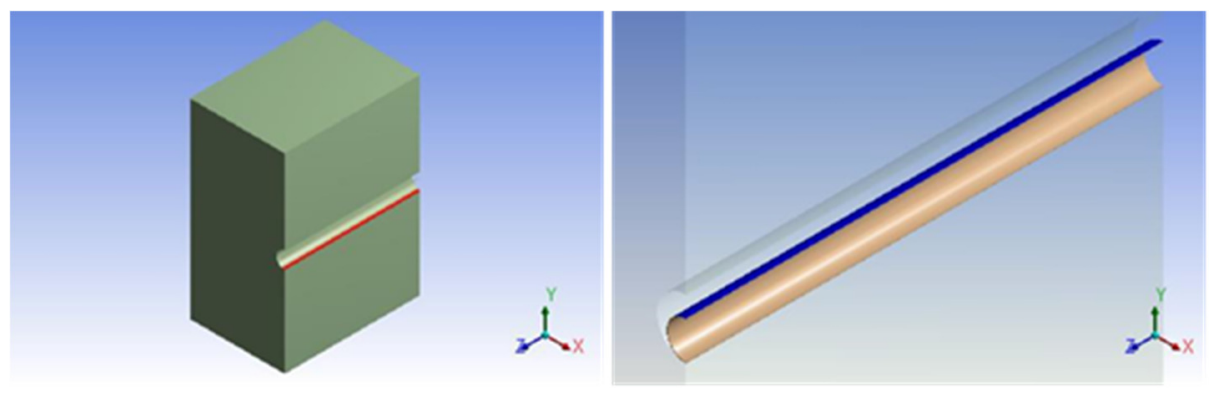

Fig. 5 Contact between the inner wall of the borehole and the outer wall of the pipe

The hydrostatic pressure of a curved surface can be calculated automatically. When the density of drilling fluid is $1200 \mathrm{~kg} / \mathrm{m} 3$, the calculation results of the hydrostatic pressure acting on the borehole wall and the outer wall of the pipeline are shown in Fig. 6 and Fig. 7.

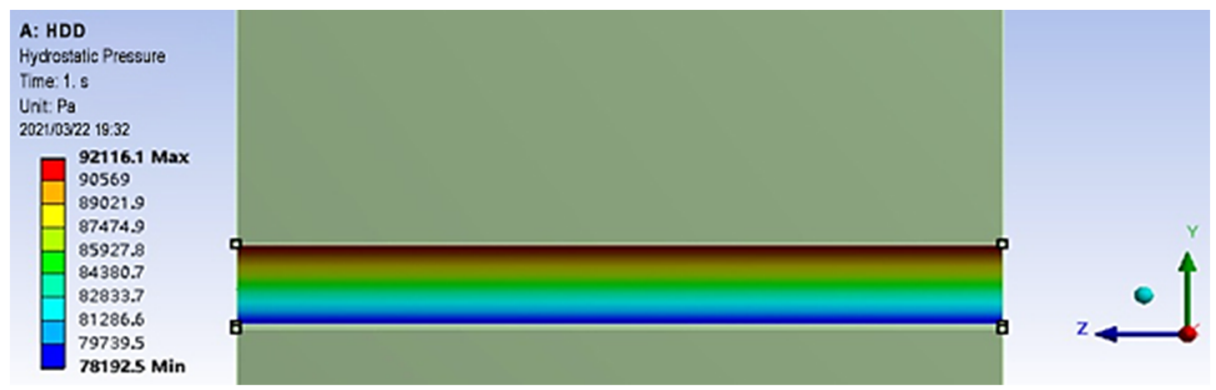

Fig. 6 The hydrostatic pressure acting on the borehole wall

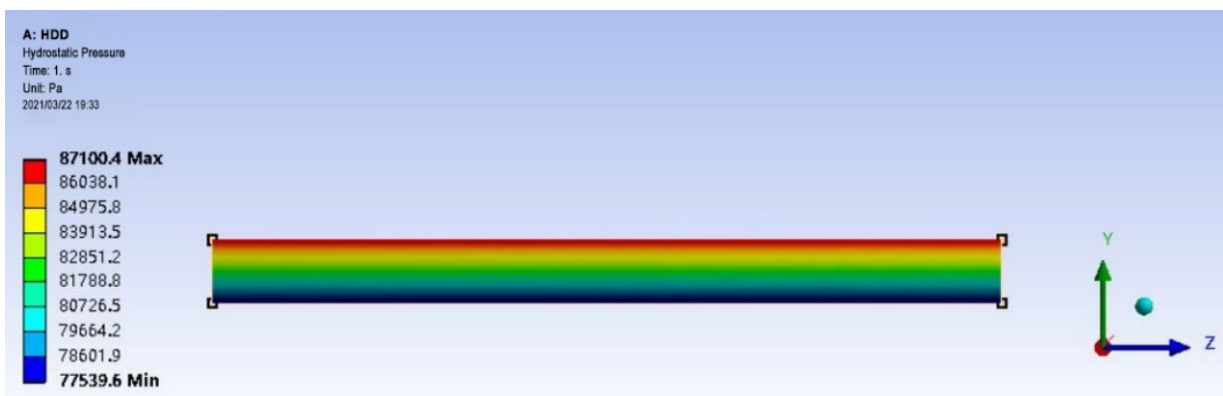

Fig. 7 The hydrostatic pressure acting on the outer wall of the pipe

It shows that the hydrostatic pressure on the upper part of the pipeline is greater than that on the lower part. Based on the above analysis, all loads in this scenario are shown in Fig.8. 


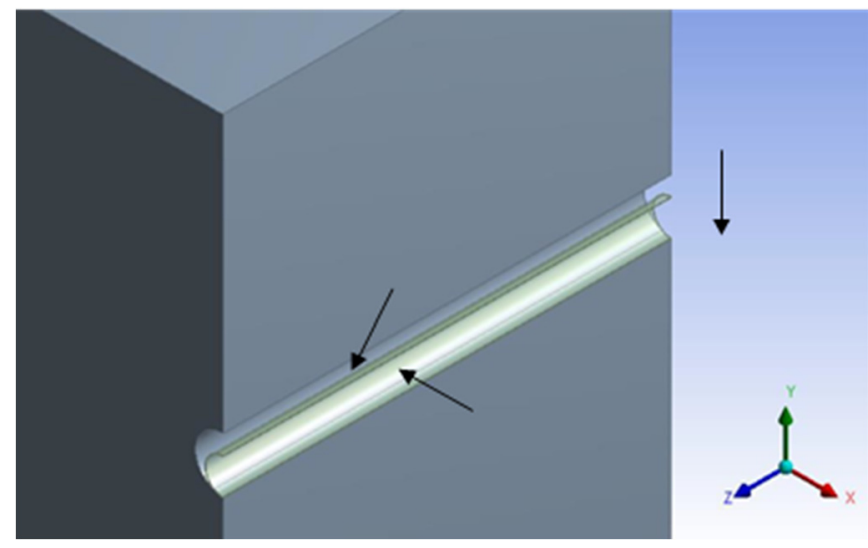

Fig. 8 Loads for this scenario

A free boundary conditions of the pipe-soil system at both ends of the pipeline is presented in the figure 9 (a).

In case of a fixed boundary condition can be observed a stress concentration at both ends of the pipe as is shown in the figure (b).

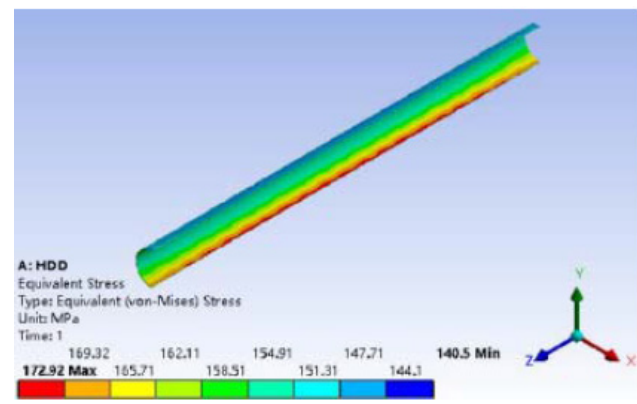

(a)

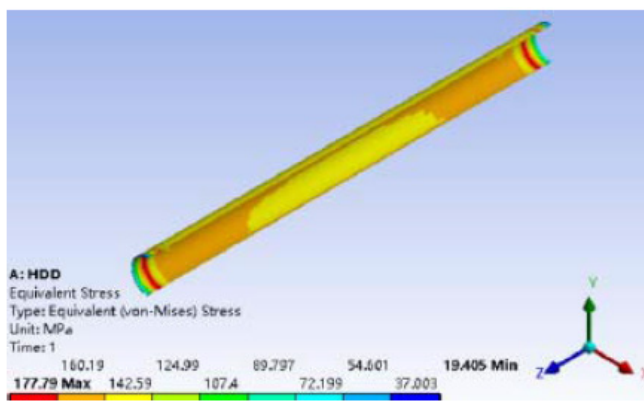

(b)

Fig. 9 Equivalent stress nephogram of pipeline: (a) free boundary conditions; (b) fixed boundary conditions

\section{Installation of submarine cables and pipes in shallow water}

The installation of submarine cables in deep water is done with specialized ships and stateof-the-art equipment. Unfortunately, the installation and repair of submarine cables in shallow water remains a challenge, and it is necessary to develop new concepts to ensure increased efficiency and reduced environmental impact.

It is observed that in many projects, for the connection to the shore of the submarine cables, the installing's used techniques, often lead to cable damage and increase the costs of these operations, having a negative impact on the environment. This leads to the decision to use various types of pontoons or barges, with various technical capabilities, with or without their own propulsion. Unfortunately, these installation methods involve the use of a large number of tugs and / or other equipment (Fig.10) [5] 


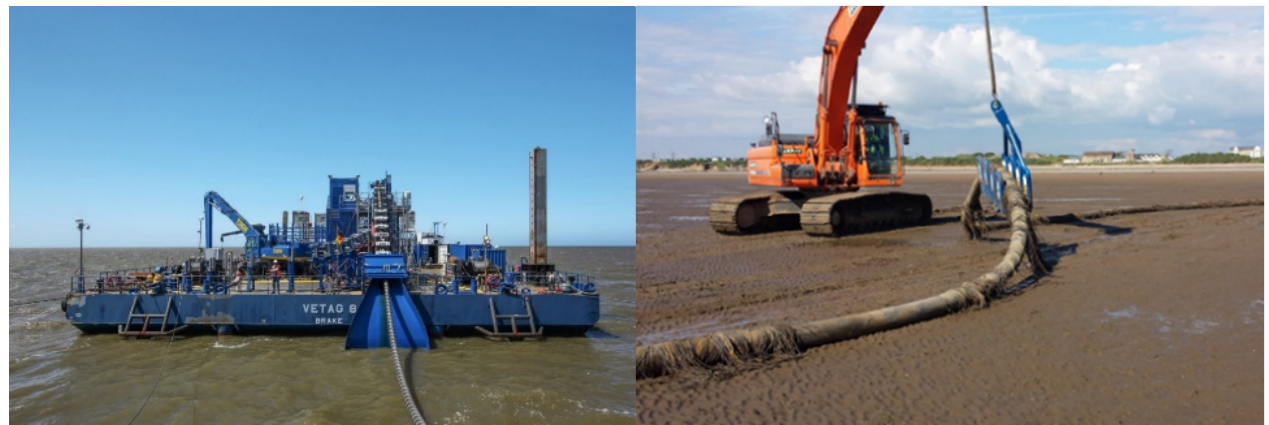

Fig. 10 CLV VETAG 8 and crawler excavator into intertidal zone [5]

The Waves and sea currents action can affect submarine cables by the forces developed by the action of water or by redistribution of sediments. The action of the waves is stronger on the shore or in shallow waters and decreases with increasing depth. In general, the action of the waves stops at a depth of about $30 \mathrm{~m}$. Only exceptionally, during strong storms the action of the waves is felt more deeply. Coastal areas, especially sandy ones, are undergoing the most dramatic changes due to the action of waves. In such cases, if the cable or pipes are not enough buried, they can be brought to the surface (Fig. 11) [6]

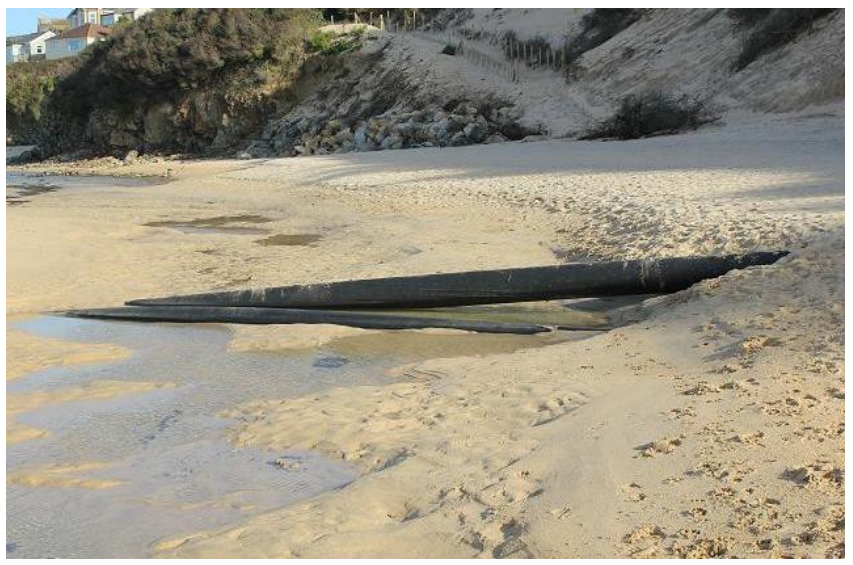

Fig. 11 Cable unearthed under the action of waves [6]

\section{Benefits of using HDD for installation of submarine cables and pipes}

Nowadays there is an increase in interest in the use of horizontal directional drilling in the installation of cables and pipes [7]. Bellow I want to show you the most important benefits of using HDD:

- requires a relatively short installation period (the standby time due to weather windows is eliminated)

- relatively low installation costs

- reduces the impact on the environment being a less invasive technique than traditional open cutting

- reduction of carbon emissions due to the low number of tugs and / or other equipment used for installation operations 
- minimizes the negative impact on other installations or networks of cables and / or pipes installed in the same area

- does not require interruption of maritime traffic

- reduces the environmental impact of any activities on the sea bottom, above the pipeline or cable (in case of preventive or corrective maintenance's works or even decommissioning's activities)

- increasing the safety of operation (even in the case of anchoring ships in dangerous situations, due to force majeure)

- also makes possible the installation of less resistant pipes to the classic installation operations, respectively liquid hydrogen transport pipes

\section{Conclusions}

Having in mind that this article is only part of a major research on the installation of submarine cables in the offshore wind industry we like to present here only the method of installing a submarine pipe using HDD. The installation of the cables through these pipes being only a later stage with multiple advantages presented in the previous chapter.

Trusting that this technique will be used more and more often and not only when it is the only technical solution due to constraints, I would like to draw the following conclusions:

The simulation analysis shows that the loads on the pipe during installation and later on during operation do not exceed the design values

Through the influencing factor analysis and stress sensitivity analysis, it is concluded that the sensitivity order (from high to low) of five factors to pipeline stress are as follows: diameter -thickness - pressure - drilling fluid density - buried depth

As it has become the case in our days that suspended networks in large cities are moved underground in the near future will have to do the same with all submarine pipes or cables in coastal and shallow water areas. This technique seems to be the key to success

Even though the horizontal directional drilling technique has become very popular nowadays and most of the submarine cable and pipeline installation operations performed so far have been successful, this technique still cannot guarantee control over the risks from underground. For these reasons, in order to improve this technique with the main purpose of increasing the length of these boreholes horizontally, we consider that encouraging research in this field is of major importance

Performance of a risk analysis can help to control the risks.

\section{References}

1. T. Iseley, S.B. Gokhale, Synthesis of highway practice 242: trenchless installation of conduits beneath roadways. Transportation Research Board, National Academy Press, Washington (1997)

2. A. Atalah, J. Kariuki, Cost Comparison between Horizontal Directional Drilling and Open-Cut Construction Methods in Nairobi, Kenya, International Conference on Pipelines and Trenchless Technology (2009)

3. S.J. Jariwala, J. Pitroda, J.J. Bhavsar, Horizontal Directional Drilling: New Era for Underground Utilities, Proceedings of National Conference CRDCE13, 20-21 December 2013, SVIT, Vasad

4. R. Wisniowski, P. Lopata, G. Orlowicz, Numerical Methods for Optimization of the Horizontal Directional Drilling (HDD) Well Path Trajectory, MDPI July (2020) 
5. V.F. Vasilescu, D. Dinu, Installation of Submarine Cables in The Offshore Wind Industry and Their Impact on The Marine Environment, Journal of Marine Technology and Environment, 1 (2021)

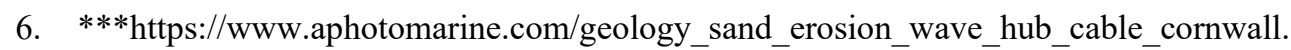
$\mathrm{html}$ accessed on 15.09.2020

7. H.J. Bayer, HDD practice handbook, Vulkan Verlag, Essen (2005) 